Journal of Maternal and Child Health (2017), 2(3): 258-270

https://doi.org/10.26911/thejmch.2017.02.03.07

\title{
Factors Affecting the Occurrence of Mental Disability in Ponorogo District, East Java
}

\author{
Risye Endri Purwiyanti'), RB. Soemanto2), Yulia Lanti Retno Dewi3) \\ ${ }^{1)}$ Masters Program in Public Health, Universitas Sebelas Maret \\ 2) Faculty of Social and Political Sciences, Universitas Sebelas Maret \\ 3)Department of Nutrition, Faculty of Medicine, Universitas Sebelas Maret
}

\begin{abstract}
Background: Children with mental disability show below average intellectual abilities and social behavior adaptability. Living with a disabled child can have profound effects on the entire familyparents, siblings, and extended family members. Meeting the needs of children with disabilities can be challenging for schools and families. However, effective support for children's mental health and wellbeing involves efforts to meet the social, emotional and learning needs of all children. This study aimed to investigate factors affecting the occurrence of mental disability in children aged 6 to 15 years old.

Subjects and Method: This was an analytic observational study using case control design. The study was conducted in Ponorogo District, East Java, from March to April 2017. A sample of 150 children aged 6 to 15 years old, consisting of 50 children with mental disability and 100 children without mental disability, were selected for this study by fixed disease sampling. The exogenous variables were prematurity, maternal age during pregnancy, maternal stress during pregnancy, hereditary history, family income, parental education, and environmental exposure. The endogenous variables were maternal nutritional status, low birthweight, and mental disability. The data were collected by a questionnaire, and analyzed by path analysis.

Results: Mental disability was directly affected by maternal age $(b=2.52,95 \% \mathrm{CI}=1.23$ to 3.81 , $\mathrm{p}<0.001$ ), low birthweight ( $\mathrm{b}=2.32,95 \% \mathrm{CI}=1.11$ to $3.54, \mathrm{p}<0.001)$, hereditary history $(\mathrm{b}=2.54$, $95 \% \mathrm{CI}=1.34$ to $3.74, \mathrm{p}<0.001$ ). Mental disability was indirectly affected by maternal nutritional status, maternal stress, maternal education, family income, and environmental exposure.

Conclusion: Maternal age, low birthweight, and hereditary history, directly affect mental disability. Maternal nutritional status, maternal stress, maternal education, family income, and environmental exposure, indirectly affect mental disability.
\end{abstract}

Keywords: mental disability, children aged 6 to 15 years old

\section{Correspondence:}

Risye Endri Purwiyanti. Masters Program in Public Health, Universitas Sebelas Maret. Jl. Ir. Sutami 36 A, Surakarta, Central Java 57126. Email: risye310390@gmail.com.

Mobile: 085736575029.

\begin{tabular}{l}
\hline BACKGROUND \\
\hline Mental disability is a term used for children \\
who have intellectual abilities which are \\
below the average. Mental disability is an \\
integral part of Indonesia which is insepa- \\
rable from other members of the commu- \\
nity (Somantri, 2012). Mental disability \\
shows behavioral inadaptability appears \\
before the age of 18 (Ciptono and Supri- \\
yanto, 2010). The prevalence of mental \\
disability is higher in children/ adolescent \\
than adults (Maulik et al., 2011).
\end{tabular}

\section{BACKGROUND}

Mental disability is a term used for children who have intellectual abilities which are below the average. Mental disability is an integral part of Indonesia which is inseparable from other members of the community (Somantri, 2012). Mental disability shows behavioral inadaptability appears before the age of 18 (Ciptono and Supridisability is higher in children/ adolescent than adults (Maulik et al., 2011).
There are almost 83 million of the world's population is estimated to experience mental disability (WHO, 2013). About a quarter of cases are caused by gene-abnormalities and 5\% of cases are inherited from parents. About 95 million people experienced disability in 2013 and the cause was not found (Global Burden of Disease Study 2013 Collaborators, 2015). According to the results of the National Socio-Economic Survey conducted by the Central Bureau of Statistics in 2012, the 
number of mental disability in Indonesia was 402,817 people (Tula, 2015).

The number of mentally disability children in Special School type C, East Java, in 2013 was 6,633 children (Education Office, 2014). The mental disability incidence in Ponorogo increased from 0.14\% in 2010 to $0.21 \%$ in 2013 (Development Planning Agency at Sub-National Level, 2013).

Mental disability is associated with several factors such as biological and psychosocial factors. Biological factors are classified into genetic and non-genetic factors. Non-genetic factors are maternal age during pregnancy, malnutrition condition during pregnancy, perinatal causes such as prematurity, low birth weight and birth trauma can contribute to the incidence of mental disability (Armatas, 2009). Psychosocial factors such as psychological trauma, poor environment, social status, low economy, and certain cultural affects when growing children will harm children's development; it causes mental disability (Persha and Rao, 2007).

Low maternal education and socioeconomic are also related to the incidence of mental disability. The worse health conditions that can affect fetus growth can cause mental disability (Maulik, 2010). The bad environment condition such as exposure to poisons can cause permanent damage to the brain and nervous system; it causes mental disability (Winnepenninckx et al., 2003).

Mental disability starts in childhood and involves less mental abilities, social skills, and daily activities compared to his friends with the same age (Kaneshiro and Neil, 2015). People with mental disability have a higher risk of health problems such as epilepsy, neurological disorders, digestive disorders, and behavioral and psycho- logical problems than normal people (Krahn and Fox, 2013).

According to study conducted by Setyarini and Mutiah (2015) in Ponorogo District about the disorder level of mental disability based on internal factors of mental disability, it was concluded that several factors which play a role in the disorder level of mental disability were birth assistance, birth weight, and program of monitoring growth and development in a child. Patients with high mental disability disorders have a higher chance to get a program of monitoring growth and development in a child than those with lower mental disability disorders. This study aimed to investigate factors affecting the occurrence of mental disability in children.

\section{SUBJECT AND METHOD}

\section{Study Design}

This was an analytic observational study using case control design with retrospective investigation. The researcher determined the disease status first and investigated the history of backward direction. The study was conducted in Special School type C and elementary school in Ponorogo District from March to April 2017.

\section{Population and Sample}

The target population in this study was all mothers of children with mental disability in Ponorogo District. The sample in this study was 150 samples which were selected by fixed disease sampling using 1:2 ratio between case and control. The data were collected by a set of questionnaire, and analyzed by path analysis.

\section{Study Variable}

There were 10 variables in this study, such as exogenous and endogenous. The exogenous variables were family income, parental education, prematurity, maternal age during pregnancy, maternal stress during pregnancy, hereditary history, and 
environmental exposure. The endogenous variables were maternal nutritional status, low birth weight, and mental disability.

\section{Operational Definition of Variables}

Mental disability was defined as children who have intellectual or adaptive behavioral limitations. Maternal age during pregnancy was the life duration of a pregnant mothers from she was born to she was pregnant. Hereditary history was defined as hereditary factors inherited from parents to children.

Maternal nutritional status was the body condition of pregnant women due to the food consumption and use of nutrients measured by the maternal mid-upper arm circumference. Premature labor was defined as the result of conception that can live but have not had enough months to be born. Low birth weight was the baby's weight at birth less than 2500 grams.

Maternal stress during pregnancy was defined as partner or family support, living conditions and cultural conditions that can interfered the maternal psychological condition during pregnancy. Maternal education was the latest level of formal education completed by the mother.

Family income was defined as the total money received by the father and mother every month. Environmental exposure was exposure to cigarette smoke inhaled by mothers during pregnancy from family members and other relatives at home as passive smokers.

\section{Instrument of the Study}

The study used a set of questionnaire which was developed in accordance with the theory and which have been a subject to reliability test. Based on the reliability test, it was found that the measurement results for environmental exposure variables with a total item correlation value were 0.60 and o.81 for Cronbach's alpha, so that all items from the question are declared reliable.

\section{Data Analysis}

This study used quantitative data analysis. It was conducted univariately to show the data on the characteristics of respondents and the variable descriptive of the study; It also used bivariate analysis to analyze the effect of exogenous variables on endogenous variables using the chi square test; It used path analysis to analyze the effect of exogenous variables on endogenous variables through intermediate variables and to know the direct and indirect effects of exogenous on endogenous.

\section{RESULT}

Table 1 showed that from the 150 study subjects, most of children who in the preadolescent stage (10-15 years) were 99 subjects (66.00\%) and the least number was the early stage (6-7 years) which were 14 subjects (9.33\%). The gender on the study subjects was mostly comparable between male and female by 82 male subjects (54.67\%) and 68 female subjects (45.33\%). There were 70 subjects (46.67\%) of housewives who did not work and 4 subjects (2.67\%) of working mothers.

The descriptive statistic of dichotomous data in this study such as mental disability status in children, maternal age during pregnancy, hereditary history, maternal nutritional status during pregnancy, premature birth, LBW, maternal stress during pregnancy, maternal education, family income and environmental exposure were presented in Table 2. Table 2 showed that each variable has a different distribution. Description of study variables was explained based on characteristics, criteria, frequency and percentage (\%). 
Tabel 1. The characteristic of study subject

\begin{tabular}{lcc}
\hline \multicolumn{1}{c}{ Variables } & n & \% \\
\hline Children age & & \\
Early Stage (6-7 years) & 14 & 9.33 \\
Mid Stage (8-9 years) & 37 & 24.67 \\
Pre-adolescent (10-15 years) & 99 & 66.00 \\
Gender & 82 & 54.67 \\
male & 68 & 45.33 \\
female & & \\
Maternal Occupation & 70 & 46.67 \\
Housewife (unemployed) & 14 & 9.33 \\
labor & 21 & 14.00 \\
Farmer & 18 & 12.00 \\
Private employee & 23 & 15.33 \\
Entrepreneur & 4 & 2.67 \\
Government employee & & \\
\hline
\end{tabular}

Table 2. Univariate analysis

\begin{tabular}{|c|c|c|}
\hline Variables & $\bar{n}$ & $\%$ \\
\hline \multicolumn{3}{|l|}{ Mental Disability } \\
\hline No & 100 & 66.67 \\
\hline Yes & 50 & 33.33 \\
\hline \multicolumn{3}{|l|}{ Maternal Age during Pregnancy } \\
\hline No risk & 107 & 71.33 \\
\hline With risk & 43 & 28.67 \\
\hline \multicolumn{3}{|l|}{ Hereditary History } \\
\hline Do not have offspring & 97 & 64.67 \\
\hline Have offspring & 53 & $35 \cdot 33$ \\
\hline \multicolumn{3}{|c|}{ Maternal Nutritional status during Pregnancy } \\
\hline Low nutritional status & 46 & 30.67 \\
\hline Good nutritional status & 104 & 69.33 \\
\hline \multicolumn{3}{|l|}{ Premature Birth } \\
\hline Normal & 107 & 71.33 \\
\hline Premature & 43 & 28.67 \\
\hline \multicolumn{3}{|l|}{ Low Birth Weight } \\
\hline Normal ( $\geq 2500$ gram) & 103 & 68.67 \\
\hline Low birth weight (<2500 gram) & 47 & 31.33 \\
\hline \multicolumn{3}{|c|}{ Maternal Stress during Pregnancy } \\
\hline Mild stress & 102 & 68.00 \\
\hline Severe stress & 48 & 32.00 \\
\hline \multicolumn{3}{|l|}{ Maternal Education } \\
\hline Basic education $(<\mathrm{SMA})$ & 49 & 32.67 \\
\hline High education ( $\geq$ SMA) & 101 & 67.33 \\
\hline \multicolumn{3}{|l|}{ Family Income } \\
\hline$<$ minimum wage & 58 & 38.67 \\
\hline$\geq$ minimum wage & 92 & 61.33 \\
\hline \multicolumn{3}{|l|}{ Environmental Exposure } \\
\hline unexposed & 102 & 68.00 \\
\hline exposed & 48 & 32.00 \\
\hline
\end{tabular}

Table 3 showed that all independent variables have positive effects on mental disability incidence. The highest effect was given by maternal stress during pregnancy
$(\mathrm{OR}=35.85 ; 95 \% \mathrm{CI}=13.76$ to $93.36 ; \mathrm{p}$ $<0.001)$. The lowest effect was given by the maternal nutritional status during pregnancy which almost did not have effect on 
the incidence of mental disability $(\mathrm{OR}=$ $0.27 ; 95 \% \mathrm{CI}=0.13$ to $0.55 ; \mathrm{p}<0.001)$. Reliable findings consisted of maternal age during pregnancy, hereditary history, ma-

Table 3. Chi-Square test of factors which affect mental disability incidence

\begin{tabular}{|c|c|c|c|c|}
\hline \multirow{2}{*}{ Independent Variable } & \multirow{2}{*}{ OR } & \multicolumn{2}{|c|}{$(95 \%) \mathrm{CI}$} & \multirow[b]{2}{*}{$\mathbf{p}$} \\
\hline & & Lower Limit & Upper Limit & \\
\hline $\begin{array}{l}\text { Maternal age during } \\
\text { pregnancy }\end{array}$ & 29.57 & 11.43 & 76.49 & $<0.001$ \\
\hline Hereditary history & 17.94 & 7.68 & 41.99 & $<0.001$ \\
\hline $\begin{array}{l}\text { Maternal nutritional } \\
\text { status during pregnancy }\end{array}$ & 0.27 & 0.13 & 0.55 & $<0.001$ \\
\hline Prematurity & 17.47 & 7.27 & 42.00 & $<0.001$ \\
\hline LBW & 32.02 & 12.46 & 82.26 & $<0.001$ \\
\hline $\begin{array}{l}\text { Maternal stress during } \\
\text { pregnancy }\end{array}$ & 35.85 & 13.76 & $93 \cdot 39$ & $<0.001$ \\
\hline Maternal education & 1.60 & 0.75 & 3.40 & 0.218 \\
\hline Family income & 1.04 & 0.52 & 2.10 & 0.906 \\
\hline Environmental exposure & 7.97 & 3.68 & 17.27 & $<0.001$ \\
\hline
\end{tabular}

ternal nutritional status during pregnancy, prematurity, LBW, maternal stress during pregnancy, and environmental exposure because it has $\mathrm{p}<0.05$.

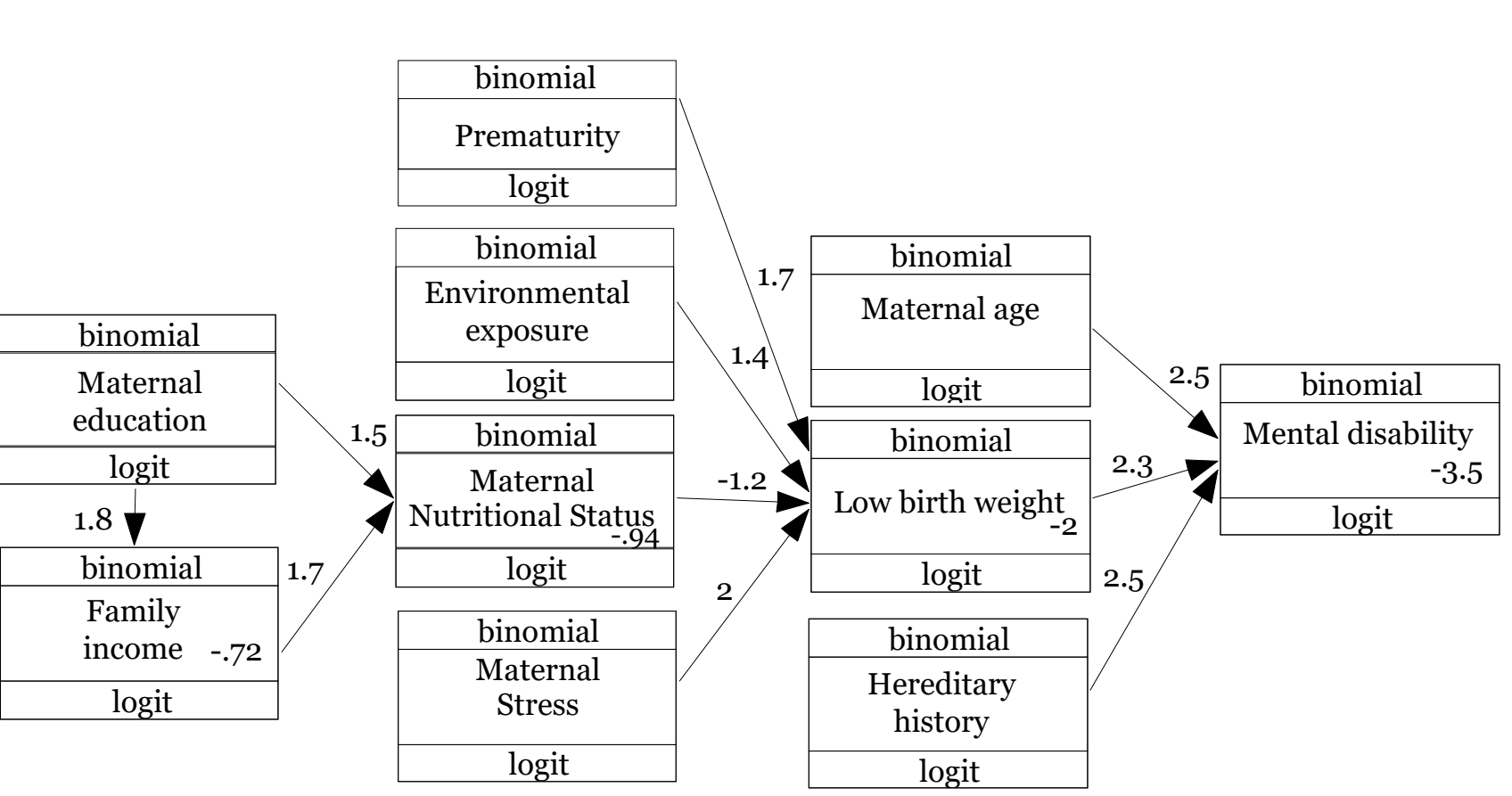

\section{Figure 1. Structural Model of Path Analysis}

Figure 1 showed the structural model after estimation using IBM SPSS STATA 13, so that the value could be obtained.

Table 4 showed that mental disability was directly affected by maternal age during pregnancy, LBW, and hereditary history. In addition, mental disability was indirectly affected by prematurity, environmental exposure, maternal nutritional status, maternal stress, maternal education, family income.

Maternal age that had risk during pregnancy had an average logodd score of the incidence of mental disability by 2.52 points higher than maternal age that was not at risk during pregnancy $(b=2.52 ; 95 \%$ $\mathrm{CI}=1.23$ to $3.81 ; \mathrm{p}<0.001)$. LBW had an average logodd score of mental disability incidence by 2.32 points higher than the 
normal birth weight $(\geq 2,500$ grams) (b = $2.32 ; 95 \% \mathrm{CI}=1.11$ to $3.54 ; \mathrm{p}<0.001)$. Hereditary history had an average logodd score of mental disability by 2.54 points higher than families with no hereditary history $(\mathrm{b}=2.54 ; 95 \% \mathrm{CI}=1.34$ to $3.74 ; \mathrm{p}$ $<0.001)$.

LBW was affected by prematurity, environmental exposure, maternal nutritional status during pregnancy, and maternal stress during pregnancy. Prematurity has an average logodd score of LBW by 1.70 points higher than baby that had enough months $(b=1.70 ; 95 \% \mathrm{CI}=0.52$ to $2.88 ; \mathrm{p}=$
0.005). The exposed environment had an average logodd score of LBW by 1.38 points higher than the unexposed environment $(b=1.38 ; 95 \% \mathrm{CI}=0.19$ to $2.57 ; \mathrm{p}=0.023$ ). Good maternal nutritional status had an average logodd score of LBW by 1.21 points lower than low maternal nutritional status $(b=-1.21,95 \% \mathrm{CI}=-2.35$ to $-0.76 ; \mathrm{p}=$ o.036). Mothers who experienced severe stress during pregnancy had an average logodd score LBW by 2.04 points higher than mothers who experience mild stress during pregnancy $(\mathrm{b}=2.04 ; 95 \% \mathrm{CI}=0.94$ to 3.13 ; $\mathrm{p}<0.001$ ).

Table 4. The path analysis result of factors which affect mental disability incidence

\begin{tabular}{|c|c|c|c|c|c|c|}
\hline \multirow[b]{2}{*}{ Endogenous Variables } & \multirow{2}{*}{\multicolumn{2}{|c|}{$\begin{array}{c}\text { Exogenous } \\
\text { Variabel }\end{array}$}} & \multirow[b]{2}{*}{$\mathbf{b}$} & \multicolumn{2}{|c|}{ CI (95\%) } & \multirow[b]{2}{*}{$\mathbf{p}$} \\
\hline & & & & $\begin{array}{l}\text { Lower } \\
\text { Limit }\end{array}$ & $\begin{array}{l}\text { Upper } \\
\text { Limit }\end{array}$ & \\
\hline \multicolumn{7}{|l|}{ Direct effect } \\
\hline Mental disability & $\leftarrow$ & $\begin{array}{l}\text { Maternal age during } \\
\text { pregnancy }\end{array}$ & 2.52 & 1.23 & 3.81 & $<0.001$ \\
\hline Mental disability & $\leftarrow$ & LBW & 2.32 & 1.11 & 3.54 & $<0.001$ \\
\hline $\begin{array}{l}\text { Mental disability } \\
\text { Indirect effect }\end{array}$ & $\leftarrow$ & Hereditary history & 2.54 & 1.34 & 3.74 & $<0.001$ \\
\hline LBW & $\leftarrow$ & Prematurity & 1.70 & 0.52 & 2.88 & 0.005 \\
\hline LBW & $\leftarrow$ & $\begin{array}{l}\text { Environmental } \\
\text { exposure }\end{array}$ & 1.38 & 0.19 & 2.57 & 0.023 \\
\hline LBW & $\leftarrow$ & Nutritional status & -1.21 & -2.35 & -0.76 & 0.036 \\
\hline LBW & $\leftarrow$ & Maternal stress & 2.04 & 0.94 & 3.13 & $<0.001$ \\
\hline $\begin{array}{l}\text { Maternal } \\
\text { nutritional status }\end{array}$ & $\leftarrow$ & Maternal education & 1.47 & 0.63 & 2.31 & 0.001 \\
\hline $\begin{array}{l}\text { Maternal } \\
\text { nutritional status }\end{array}$ & $\leftarrow$ & Family income & 1.65 & 0.81 & 2.49 & $<0.001$ \\
\hline Family income & $\leftarrow$ & Maternal education & 1.84 & 1.09 & 2.58 & $<0.001$ \\
\hline $\begin{aligned} \text { Log Likelihood } & =-244.18 \\
\text { AIC } & =516.36\end{aligned}$ & & & & & & \\
\hline $\mathrm{BIC}=558.53$ & & & & & & \\
\hline
\end{tabular}

Maternal nutritional status during pregnancy was affected by maternal education and family income. Mothers who had higher education have an average logodd score of maternal nutritional status by 1.47 points higher than mothers with low education $(b=1.47 ; 95 \% \mathrm{CI}=0.63$ to $2.31 ; \mathrm{p}=$ o.o01). High family income had an average logodd score of maternal nutritional status by 1.65 points higher than the low family income $(\mathrm{b}=1.65 ; 95 \% \mathrm{CI}=0.81$ to $2.49 ; \mathrm{p}$ $<0.001)$.

Family income was affected by maternal education. Mothers who had higher education had an average logodd score of family income by 1.84 points higher than mothers who had low education $(b=1.84$; $95 \% \mathrm{CI}=1.09$ to $2.58 ; \mathrm{p}<0.001$ ). 


\section{DISCUSSION \\ 1. The effect of maternal age during pregnancy on mental disability}

There was a positive and significant effect between maternal age during pregnancy and the mental disability incidence. The maternal age which was at risk (too old or too young) during pregnancy could increase the mental disability incidence.

This study result is in line with the meta-analysis study conducted by Huang et al., (2016). This study stated that maternal age more than 35 years during pregnancy had a positive correlation or more risky of giving birth to mental disabled child. Maternal age over 35 years during pregnancy increased 1.5 times the mental disability incidence compared to mothers who were pregnant at less than 35 years $(\mathrm{OR}=$ 1.53; $95 \% \mathrm{CI}=1.35$ to $1.72 ; \mathrm{p}<0.001$ ).

Pregnant mothers who are at age less than 20 years or over 35 years will be at higher risk of experiencing obstetric complications and perinatal morbidity and mortality. Ages that are too young physically and psychologically are still immature. Ages that are too old are related to deterioration and decreased endurance, as well as various diseases such as hypertension, diabetes, placental abruption, premature birth, stillbirth, poor fetal growth and placenta previa. The age of mothers that are getting younger or older when pregnant will be at risk of experiencing complications during pregnancy and labor (Cavazos et al, 2015).

Hormonal changes can cause cleavage failure on chromosome 21. It causes downsyndrome which causes mental retardation or mental disability in children. This phenomenon can increase due to the increase of maternal age (Allen et al, 2009). Maternal age during pregnancy affects the incidence of mental disability. Pregnancy that occurs outside the age of a healthy repro- duction will be at risk of experiencing pregnancy complications. It affects the fetal brain development and causes the incidence of mental disability (Katiyar and Gupta, 2014).

\section{The effect of hereditary history on mental disability}

There was a positive effect between hereditary history and mental disability incidence. The hereditary history could increase the mental disability incidence.

This research is in line with the study result conducted by Jain et al (2013) in India on 101 children with mental disability. The result stated that $82.1 \%$ mental disability were caused by genetics and followed by perinatal, malformation, prenatal and postnatal problems. Genetic problems are the biggest cause in increasing the incidence of mental disability.

Genetic factors have an important role which is related to the causes of mental disability. Some chromosomal abnormallities are inherited from parents. Hereditary factors occur due to the damage of the body's biochemical structure and abnormalities on the chromosomes (Armatas, 2009). Family history of experiencing mental disability can increase the possibility of mental disability in the next generation. Family history can help in making a diagnosis, especially when other family members experience the same case (Moeschler et al, 2006).

\section{The effect of maternal nutritional status towards mental disability incidence}

There was a negative effect between maternal nutritional status during pregnancy and the mental disability incidence through low birth weight. Good maternal nutritional status reduced the low birth weight incidence and the risk of mental disability.

This study is in line with the results of a study conducted by Sen et al. (2010) 
which showed that maternal nutritional status during pregnancy affected LBW incidence. Another study conducted by Assefa et al. (2012) showed the results that maternal mid-upper arm circumference (MUAC) by $<23.5 \mathrm{~cm}$ had a greater risk of increasing the incidence of LBW by 1.6 times greater than mothers with MUAC by $\geq 23.5 \mathrm{~cm}$.

Nutritional status is a measure of success in fulfilling nutrition for pregnant women. LBW is associated with several maternal factors, such as the measurement of MUAC. Mothers who have MUAC by $<23.5 \mathrm{~cm}$ are more risky of giving birth with LBW than those who have MUAC by $\geq 23.5$ $\mathrm{cm}$ (Sarkar, 2008). MUAC is an indicator to measure maternal nutritional status. It can be used as a strong predictor in indicating the incidence of LBW (Dubois and Girard, 2006).

Maternal nutritional status in the first trimester will greatly affect embryo growth. Malnutrition which occurs to fetus will be at risk of making LBW and less optimal growth to the fetus (Sharma and Mishra, 2014). Maternal nutritional status during pregnancy plays an important role in the growth of the fetus in the uterus. Poor maternal nutritional status will affect shortterm and long-term health problems such as neurological disorders, inability to learn and mental disability (Purandare, 2012).

\section{The effect of prematurity on mental disability incidence}

There was a positive effect between prematurity and mental disability incidence through LBW. Premature labor could increase the incidence of LBW and this can be risky to increase tmental disability incidence.

This study is in line with the results of a study conducted by Sharma et al (2015) which showed that the history of premature labor had a positive and significant effect on LBW with a risk of 5.24 times greater than those who had enough months to be born.

Premature labor is a labor from the results of a conception which is not enough months, the old pregnancy between 28 weeks to 36 weeks, or the fetal weight between 1,000-2,500 grams (Wiknjosastro, 2007). Premature babies have a greater risk of experiencing neurodevelopmental disorders that are significant for the short and long term (Jarjour, 2015).

Premature labor could increase the risk of giving birth with under normal body weight $(<2,500 \mathrm{~g})$. A baby with under normal body weight or low birth weight will be more risky for receiving intellectual or mental disability (Tsai et al, 2014).

\section{The effect of low birth weight on mental disability incidence}

There was a positive effect between LBW and the incidence of mental disability. Babies born with LBW could increase the risk of mental disability. The study result is in accordance with the study result of a meta-analysis conducted by Huang et al. (2016) which stated that LBW had a positive and significant correlation with the incidence of mental disability. LBW increased the incidence of mental disability by 3.6 times compared to babies born with normal weight.

Baby's birth weight is an intrauterine growth index which is a sensitive predictor of long-term physical and psychosocial growth and development. Intrauterine growth and development is one of the most susceptible processes in the human life cycle and the deviation causes permanent effects in the future (Metgud et al, 2012). LBW is a birth weight of less than 2500 grams regardless of gestational age. Babies with low birth weight are more at risk to neurologic deficit, including late developmental and growth and have a greater risk 
of experiencing mental disability (Tsai et al, 2014).

\section{The effect of maternal stress during pregnancy towards on dis- ability}

There was a positive effect between maternal stress during pregnancy through low birth weight babies. Maternal stress during pregnancy could increase the incidence of low birth weight and and it is susceptiple of experiencing the incidence of mental disability.

This study is in line with the results of a study conducted by Rasyid et al (2013) which stated that the severe stress had a positive and significant effect on the incidence of LBW. Mothers who experienced severe stress had a risk of 1.7 times greater than mothers who did not experience stress or experienced mild stress during pregnancy. Another study conducted by Monk et al. (2012) stated that severe stress during pregnancy could increase the risk of premature babies, LBW, inhibition of neuronal and cognitive development in children, hyperactivity disorders and other mental health disorders.

Stress is a person's response both physically and mentally to a change in her environment which makes her feel disturbed and threatened (Anoraga, 2009). Pregnant mothers who experience stress can be caused by several factors such as the bad experience of mothers before pregnancy, the effects of pregnancy that effect the life of the mother, especially for working mothers, the anxiety of the ability become a mother, the finance, and the household affairs, the acceptance of pregnancy of mother, and discomfort feeling during pregnancy. These situation cause the increase of the cortisol hormone and stimulates the prostaglandin hormone, so that the uterus contracts prematurely. It causes contraction to the blood vessels; therefore, the fetus experiences malnutrition through the placenta and potentially causes LBW to the babbies (Dunkel and Tanner, 2012).

\section{The effect of maternal education on mental disability}

There was the effect of maternal education towards the incidence of mental disability through family income, maternal nutritional status during pregnancy, and LBW. High maternal education could affect the high family income. It could improve the nutritional status of mothers and reduce the incidence of LBW. Therefore, it can decrease the risks of mental disability incidence.

This study is in line with the results of a study conducted by Dharmayanti et al. (2015) which showed that families with high socio-economic status, both in education, employment, and income, had greater economic capacity to maintain the health their families. Another study conducted by Hunter et al. (2013) stated that low socioeconomic (education and income) could increase 2.17 times the incidence of down syndrome, the highest cause of mental disability incidence.

Maternal education level is the highest formal education that had been successfully taken by the mother. The higher education level which someone have will make her abilities is higher. It has an effect on increasing knowledge and better skills. Education is one of the factors which makes someone is easier to find and obtain information, so that she can increase knowledge, get job and high income easily (Ali, 2009). Maternal education is related to the incidence of mental disability. Low maternal education increases the higher risk of mental disability compared to the higher maternal education (Zheng et al., 2012). 


\section{The effect of family income on mental disability incidence}

There was an effect of family income towards the incidence of mental disability through maternal nutritional status and LBW. High family income could improve maternal nutritional status and decrease the incidence of LBW, so that it could decrease the incidence of mental disability.

This study is in line with the study result conducted by Ghosh et al. (2017) which indicated that income had a positive and significant effect on MUAC. Mothers from high income families had MUAC of o.6 times greater than mothers from low income families.

Income is the total received by the family in the form of money and goods. Family income affects the maternal knowledge level. The higher family income will make the higher maternal knowledge level about nutrition. A good maternal knowledge of nutrition will make mothers fulfill their nutritional needs easily. It will increase maternal nutritional status (Daba et al., 2013).

The highest risk of mild mental disability occurs in the children with low socio-economic status (Maulik et al., 2011). The low level of family income increases the higher risk of mental dsability incidence compared to the high family income (Boyle et al., 2011).

\section{The effect of environmental expo- sure on mental disability}

There was a positive effect between environmental exposure and the incidence of mental disability through LBW. Environmental exposure could increase the incidence of LBW. This condition could increase the risk of experiencing mental disability.

One of the environmental exposures which can increase in the incidence of LBW is exposure to cigarette smoke during preg- nancy. Exposure to cigarette smoke during pregnancy can be obtained from active and passive smokers. Smoking during pregnancy causes LBW and disabilities to the babies. Smoking which is done doubled compared to the usual causes a risk of LBW. Babies born from smokers have an average weight of 200 grams less than babies born to mothers who are not smokers (Anderka et al, 2010). This is in accordance with a study result conducted by Rasyid et al. (2013) which showed that exposure to cigarette smoke during pregnancy had a significant effect on the incidence of LBW with a risk of 4.2 times greater than mothers who were unexposed to cigarette smoke.

Pregnant mothers who are both active and passive smokers (exposed to cigarette smoke) will contaminate toxic substances such as nicotine and monoxide from cigarette smoke to the fetus through blood circulation. Nicotine causes contraception of blood vessels. It causes the decrease of bloodstream to the fetus through the umbilical cord. Therefore, it will decrease the ability to distribute nutrients needed by the fetus. Carbon monoxide will bind hemoglobin in the blood. Consequently, it will decrease the work of hemoglobin which should bind oxygen to be distributed throughout the body, so that it will disrupt the food substances distribution and oxygen to the fetus (Rasyid et al, 2013).

This condition causes a decrease in baby's birth weight. Low birth weight and premature babies are more at risk of experiencing serious health problems such as chronic lifelong disabilities such as cerebral palsy, mental disability, and learning problems (Anderka et al., 2010).

\section{REFERENCE}

Ali M (2009). Pendidikan untuk Pembangunan Nasional: Menuju Bangsa In- 
donesia yang Mandiri Dan Berdaya Saing Tinggi. Jakarta: Grasindo.

Allen EG, Freeman SB, Druschel C, Hobbs CA, O’Leary LA, Romitti PA, Royle MH, Torfs CP, Sherman SL (2009). Maternal Age And Risk For Trisomy 21 Assessed by The Origin of Chromosome Nondisjunction: A Report From The Atlanta And National Down Syndrome Projects. Hum Genet 125(1): 41-52.

Anderka M, Romitti PA, Sun L, Druschel C, Carmichael S, Shaw G (2010). Patterns of Tobacco Exposure Before And During Pregnancy. Acta Obstetricia et Gynecologica Scandinavica 89 (4): 505-14.

Anoraga P (2009). Psikologi Kerja. Yogyakarta: Rineka Cipta

Armatas, V (2009). Mental Retardation: Definition, Etiology, Epidemiology and Diagnosis. Journal of Sport and Health Research 1(2): 112-122.

Assefa N, Berhane Y, Worku A (2012). Wealth Status, Mid Upper Arm Circumference (MUAC) and Antenatal Care (ANC) Are Determinants for Low Birth Weight in Kersa, Ethiopia. PLoS One 7(6): e39957.

BAPPEDA (2013). Ponorogo Dalam Angka 2013. Ponorogo: Badan Perencanaan dan Pembangunan Daerah Kabupaten Ponorogo.

Boyle CA, Boulet S, Schieve LA, Cohen RA, Blumberg SJ, Yeargin AM, Visser S (2011). Trends In The Prevalence Of Developmental Disabilities In U.S. Children, 1997-2008. Pediatrics 127 (6): 1034-1042.

Cavazos RPA, Krauss MJ, Spitznagel EL, Bommarito K, Madden T, Olsen MA, Subramaniam H, et al (2015). Maternal Age And Risk of Labor And Delivery Complications. Matern Child Health J 19(6): 1202-1211
Ciptono, Supriyanto S (2010). Bina Diri Anak Tunagrahita. Dinas Pendidikan Provinsi Jawa tengah: Karya Ilmiah Disampaikan Pada Pelatihan Guru Pembimbing Khusus BP Diksus Provinsi Jawa Tengah.

Daba G, Beyene F, Fekadu H, Garoma W (2013). Assessment of Knowledge of Pregnant Mothers on Maternal Nutrition and Associated Factors in Guto Gida Woreda, East Wollega Zone, Ethiopia. J Nutr Food Sci 3(6): 1000235 .

Dharmayanti I, Hapsari D, Azhar K (2015). Asthma among Children in Indonesia: Causes and Triggers. Jurnal Kesehatan Masyarakat Nasional 9(4): 320326.

Dinas Pendidikan (2014). Data dan Informasi Sekolah dan Siswa Sekolah Pendidikan Khusus Tahun 2013/ 2014. Pemerintah Propinsi Jawa Timur Bidang PK-PLK.

Dubois L, Girard M (2006). Determinants of Birthweight Inequalities: Population based study. Ottawa, Canada. Pediatrics International 48: 470-478.

Dunkel SC, Tanner L (2012). Anxiety, Depression and Stress in Pregnancy: Implications for Mothers, Children, Research, and Practice. Curr Opin Psychiatry 25: 141-148.

Ghosh S, Trevino JA, Davis D, Shrestha R, Bhattarai A, Anusree KC, Pokharel A, et al (2017). Factors Associated With Mid Upper Arm Circumference In Pregnant Women In Banke, Nepal. The FASEB Journal 31 (1).

Global Burden of Disease Study 2013 Collaborators (2015). Global, regional, and national incidence, prevalence, and years lived with disability for 301 acute and chronic diseases and injuries in 188 countries, 1990-2013: A systematic analysis for the global 
burden of disease study 2013. The Lancet 386 (9995) : 743-800.

Huang J, Zhu T, Qu Y, Mu D (2016). Prenatal, Perinatal and Neonatal Risk Factors for Intellectual Disability: A Systemic Review and Meta-Analysis. PLoS ONE 11(4): e0153655.

Hunter JE, Allen EG, Shin M, Bean LJ, Correa A, Druschel C, Hobbs CA, et al (2013). The Association Of Low Socioeconomic Status And The Risk Of Having A Child With Down Syndrome: A Report From The National Down Syndrome Project. NIH Public Access 15(9); 698-705.

Jain S, Chowdhury V, Juneja M, Kabra M, Pandey S, Singh A, Bhattacharya M, et al (2013). Intellectual Disability in Indian Children: Experience with a Stratified Approach for Etiological Diagnosis. Indian Pediatrics 50: 1125-1130

Jarjour IT (2015). Neurodevelopmental Outcome After Extreme Prematurity: A Review Of The Literature. PediatrNeurol 52(2):143-52.

Kaneshiro, Neil K (2015). Intellectual Disability. MedlinePlus, U.S. National Library of Medicine. https://medlineplus.gov/ency/article/o01523.htm Retrieved on December 12, 2016.

Katiyar J, Gupta K (2014). Pre natal and Post natal Risk Factors for Mental Retardation among Children in Varanasi. Stud Home Com Sci 8(2-3): 101107.

Krahn GL, Fox MH (2013). Health Disparities Of Adults With Intellectual Disabilities: What Do We Know? What Do We Do?.Journal of Applied Research in Intellectual Disability 27 (5): 431-446.

Maulik PK (2010). Epidemiology of Intellectual Disability. New York : Center for International Rehabilitation Re- search Information and Exchange (CIRRIE).

Maulik PK, Maya NM, Colin DM, Tarun D, Shekhar S (2011). Prevalence Of Intellectual Disability: A Meta-Analysis Of Population Based Studies. Research in Developmental Disabilities, 32: 419436.

Metgud CS, Naik VA, Mallapur MD (2012). Factors Affecting Birth Weight of a Newborn A Community Based Study in Rural Karnataka, India. PLoS ONE 7(7): e40040.

Moeschler JB, Shevell M, the Committee on Genetics (2006). Clinical Genetic Evaluation of the Child With Mental Retardation or Developmental Delays. PEDIATRICS 117 (6); 2304-2316.

Monk C, Spicer J, Champagne FA (2012). Linking Prenatal Maternal Adversity to Developmental Outcomes in Infants: The Role of Epigenetic Pathways. Dev Psychopathol 24:1361-176

Persha AJ, Arya S, Nagar RK, Behera P, Verma RK (2007). Biological And Psychosocial Predictors Of Developmental Delay In Persons With Intellectual Disability: Retrospective CaseFile Study. Asia Pacific Disability Rehabilitation Journal 18(1): 93-100

Purandare CN (2012). Maternal Nutritional Deficiencies and Interventions. The Journal of Obstetrics and Gynecology of India 62 (6): 621-623.

Rasyid PS, Hakim Buraerah H, Sirajuddin S (2013). Risk Factors of Low Birth Weight in Prof. DR. H. Aloei Saboe General Hospital Gorontalo City Gorontalo Provincie 2012. Staf Kebidanan Politeknik Kesehatan. Gorontalo.

Sarkar NN (2008). The Impact of Intimate Partner Violence on Women's Reproductive Health and Pregnancy Outcome. Informa Health care Obstetrics and Gynecology 28: 266-271 
Sharma M, Mishra S (2014). Effects of Maternal Health and Nutrition on Birth Weight of Infant. International Journal of Science and Research 3: 855-8.

Sharma SR, Giri S, Timalsina U, Bhandari SS, Basyal B, Wagle K, Shrestha L (2015). Low Birth Weight at Term and Its Determinants in a Tertiary Hospital of Nepal: A Case-Control Study. PLoS One 10(4): e0123962.

Sen J, Roy A, Mondal N (2010). Association of Maternal Nutritional Status, Body Composition and Socioeconomic Variables with Low Birth Weight in India. Journal of Tropical Pediatrics 56(4): 254-259

Setyarini EA, Mutiah S (2015). Analisis Regresi Logistik Ordinal untuk Mengetahui Tingkat Gangguan Tunagrahita di Kabupaten Ponorogo Berdasarkan Faktor-Faktor Internal Penyebab Tunagrahita. Jurnal Sains Dan Seni ITS 4 (2): 2337-3520.

Somantri S (2012). Psikologi Anak Luar Biasa. Bandung :PT. Refika Aditama
Tsai WH, Hwang YS, Hung TU, Weng SF, Lin SJ, Chang WT (2014). Association Between Mechanical Ventilation And Neurodevelopmental Disorders In A Nationwide Cohort Of Extremely Low Birth Weight Infants. Research in Developmental Disabilities 35(7): 15441550.

Tula JJ (2015). Pelayanan Penyandang Disabilitas Dalam Menggunakan Berbagai Sarana Aksebilitas. http://rehsos.kemsos.go.id/modules.php?name=News\&file $=$ article\&sid $=1890$.

Retrieved on December 14, 2016.

WHO (2013). Disability In The South East Asia Region. Geneva: WHO.

Wiknjosastro (2007). Ilmu Kebidanan Sarwono Prawirohardjo. Jakarta:YBPS

Zheng X, Chen R, Li N, Du W, Pei L, Zhang J, Ji Y, Song X, Tan L, Yang R (2012). Socioeconomic Status And Children With Intellectual Disability In China. J Intellect Disabil 56(2):212-20. 